\title{
The views of lecturers about flipped classroom model
}

Raziye Demiralay a *,

Ibrahim Akdenizli ${ }^{\text {b }}$,

Suggested Citation:

New Trends and

Issues Proceedings on Humanities and Social Sciences.

Abstract 
Proceedings on Humanities and Social Sciences.

1. Introduction 
2. Method

\subsection{Research model}

\subsection{Participant group}

Table 1. Lecturers' demographic attributes

\begin{tabular}{lll}
\hline Gender & Experience \\
\hline Branch & \\
\hline
\end{tabular}


Proceedings on Humanities and Social Sciences. 
Proceedings on Humanities and Social Sciences. 


\section{Conclusion and Discussion}

\section{References}

What the best college teachers do

Managing Technological Change: Strategies for College and University Leaders. The JosseyBass Higher and Adult Education Series

Theology \& Religion, 17

Teaching

A phenomenological study of undergraduate instructors using the inverted or flipped classroom model.

Yuksekogretim ve Bilim Dergisi 4

$$
\text { Educational Technology Research and }
$$

Development 61

TechTrends 57

Creating significant learning experiences: An integrated approach to designing college courses

Teaching 42

Journal of College Science 
Teacher and Student Perceptions on High School Science Flipped Classrooms: Educational Breakthrough or Media Hype?

Proceedings of the 8th International Conference on e-Learning

Effect of the flipped classroom model on secondary computer applications course: student and teacher perceptions, questions and student achievement.

of Economic Education, 31

International Education Research 2

EDULEARN13 Proceedings

Journal of Family and Consumer Sciences 105

Teacher perceptions of the flipped classroom: Using video lectures online to replace traditional in-class lectures

Capability and quality in higher education

The effects of the classroom flip on the learning environment: A comparison of learning activity in a traditional classroom and a flip classroom that used an intelligent tutoring system

\section{Education Next 12}

The Journal of Asia TEFL 11

the twenty-first century: Social, political, and economic challenges 2

American higher education in 